\title{
Benthic community structure in kelp forests from the Southern California Bight
}

\section{Estructura de la comunidad bentónica en los bosques de macroalgas de la cuenca del Sur de California}

\author{
Guillermo Torres-Moye ${ }^{1,2 *}$, Matthew S Edwards², Cira Gabriela Montaño-Moctezuma ${ }^{3}$ \\ ${ }^{1}$ Facultad de Ciencias Marinas, Universidad Autónoma de Baja California, Carretera Transpeninsular \\ Ensenada-Tijuana No. 3917, Fraccionamiento Playitas, Ensenada 22800, Baja California, México. \\ 2 Department of Biology, San Diego State University, San Diego, California 92182, USA. \\ ${ }^{3}$ Instituto de Investigaciones Oceanológicas, Universidad Autónoma de Baja California, Carretera \\ Transpeninsular Ensenada-Tijuana No. 3917, Fraccionamiento Playitas, Ensenada 22800, Baja California, \\ México. \\ * Corresponding author. E-mail: gtorres@uabc.edu.mx
}

\begin{abstract}
The United States and Mexico share the Southern California Bight (SCB) ecosystem in the Northeast Pacific Ocean where marine wildlife and habitats historically have been disturbed by human activities. Within this ecosystem, forests of the giant kelp Macrocystis pyrifera are critical habitats that sustain diverse biological assemblages and important fishery species. We studied patterns of temporal and spatial variability within the benthic communities of five transboundary kelp forests in California (USA) and Baja California (Mexico) over a fouryear period that included a moderate El Niño event. While the benthic marine communities shared some species, they varied significantly in community structure from each other, and the degree of dissimilarity was not related to the geographic distances among the studied habitats. Rather, species richness was significantly related to local substratum rugosity, suggesting it could be used as a proxy of relative benthic biological diversity. Temporal changes in the benthic assemblages were not consistent across all forests, and contrary to observations made during previous El Niño events in the SCB, the benthic communities did not change significantly following the 2009-2010 El Niño. Such an unexpected community response may be explained by the fact that the 2009-2010 El Niño was linked to the Modoki phenomenon, where warm sea surface temperature is focused in the central equatorial Pacific and not in the eastern Pacific Ocean. We propose that long-term conservation efforts should incorporate this ecological knowledge to support science-based decisions, binational coordination of policies, and coherent management practices including the design of transboundary conservation networks as spatial management tools for the protection, conservation, and/or restoration of the SCB ecosystem.
\end{abstract}

Key words: kelp forests, community structure, habitat complexity, benthos, Southern California Bight region.

RESUMEN. Los Estados Unidos y México comparten el ecosistema de la cuenca del Sur de California (CSC) en el noreste del océano Pacífico donde la vida silvestre y los hábitats han sido históricamente perturbados por actividades humanas. En este ecosistema, los bosques del sargazo gigante Macrocystis pyrifera son hábitats críticos que mantienen conjuntos biológicos diversos y especies pesqueras importantes. Estudiamos patrones de variabilidad espacial y temporal entre las comunidades bentónicas de cinco bosques de macroalgas transfronterizos en California (EUA) y Baja California (México) durante un periodo de cuatro años que incluyó un evento moderado de El Niño. Aunque las comunidades marinas bentónicas compartieron algunas especies, variaron significativamente en la estructura de sus comunidades y el grado de disimilitud no estuvo relacionado con las distancias geográficas entre los hábitats estudiados. Más bien, la riqueza de especies se relacionó significativamente con la rugosidad del sustrato local, lo cual sugiere que podría ser usada como un indicador de la diversidad biológica bentónica. Los cambios temporales en los conjuntos bentónicos no fueron consistentes para todos los bosques y contrariamente a las observaciones realizadas durante eventos previos de El Niño en la CSC, las comunidades bentónicas no cambiaron significativamente después de El Niño 2009-2010. Esta respuesta imprevista podría explicarse debido a que El Niño 2009-2010 estuvo relacionado con el fenómeno Modoki, en el cual la temperatura superficial cálida del mar se ubica en el Pacífico central ecuatorial y no en el océano Pacífico oriental. Proponemos que los esfuerzos para la conservación a largo plazo deberían incorporar este conocimiento ecológico para apoyar las decisiones basadas en ciencia, la coordinación de políticas binacionales y prácticas de manejo coherentes incluyendo el diseño de redes de conservación transfronteriza como herramientas de manejo espacial para la conservación y/o restauración del ecosistema de la CSC.

Palabras clave: bosques de macroalgas, estructura de la comunidad, heterogeneidad de hábitat, bentos, región de la cuenca del Sur de California. 


\section{INTRODUCTION}

The United States and Mexico share marine and terrestrial ecosystems (e.g., Broyles et al. 2005, Wolf et al. 2006, Blanchette et al. 2008) where habitat and wildlife are frequently being disturbed by human activity, thereby affecting their long-term viability. Among these, the Southern California Bight (SCB) is a highly productive marine ecosystem within the Northeast Pacific Ocean (Steneck et al. 2002) (fig. 1), whose northern and southern limits are located at Point Conception, California, USA $\left(34^{\circ} 26^{\prime} 53^{\prime \prime} \mathrm{N}, 120^{\circ} 28^{\prime} 17^{\prime \prime} \mathrm{W}\right)$, and Punta Colonet, Baja California, Mexico (30 $\left.57^{\prime} 29^{\prime \prime} \mathrm{N}, 116^{\circ} 19^{\prime} 42^{\prime \prime} \mathrm{W}\right)$, respectively (Dailey et al. 1993). The SCB region has a long history of human exploitation (e.g., Erlandson and Torben 2010) where excessive hunting and overfishing have resulted in the removal of sea otters, the ecological extinction of several abalone and fish species, and the reduction in the abundance of commercial and recreational species (Dayton et al. 1998, Tegner and Dayton 2000). As a consequence, it has become of paramount importance to protect those species that remain if we are to properly manage and conserve this important ecosystem.

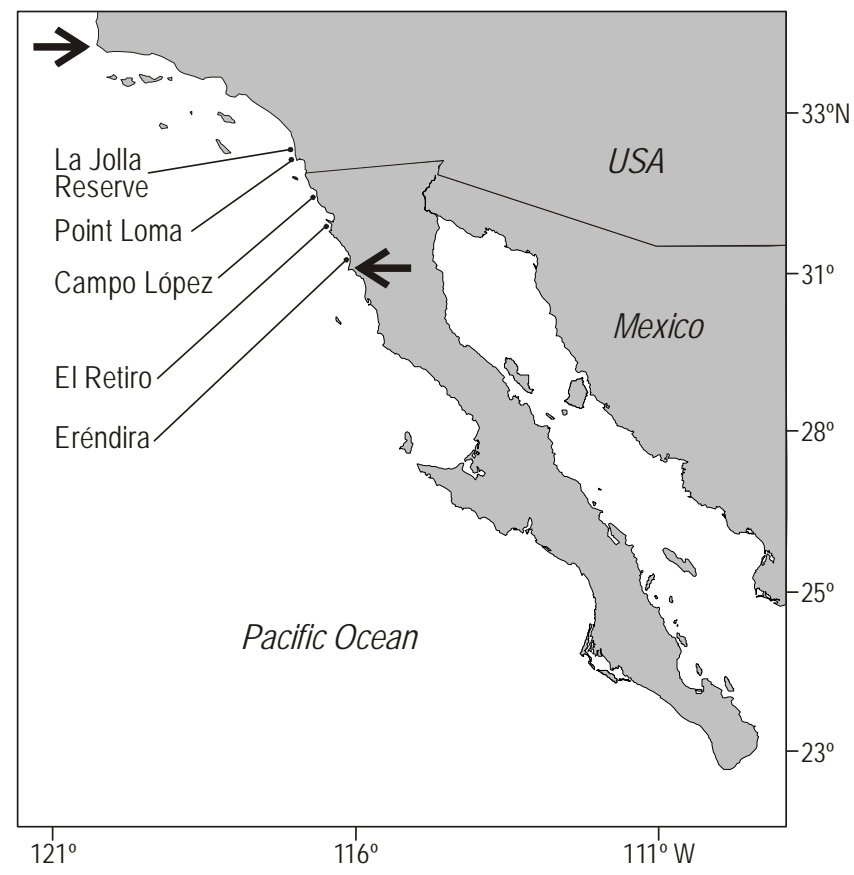

Figure 1. Map showing the five sampled mainland kelp forest sites within the Southern California Bight. The geographic limits to the Southern California Bight are shown with arrows at Point Conception, USA, and Punta Colonet, Mexico.

Figura 1. Mapa que muestra la ubicación de los cinco sitios de bosques de macroalgas estudiados en la cuenca del Sur de California. Las flechas indican los límites geográficos de la cuenca del Sur de California en Point Conception, EUA, y Punta Colonet, México.

\section{INTRODUCCIÓN}

Los Estados Unidos y México comparten ecosistemas marinos y terrestres (e.g., Broyles et al. 2005, Wolf et al. 2006, Blanchette et al. 2008) donde el hábitat y la vida silvestre son comúnmente perturbados por actividades humanas que afectan su viabilidad a largo plazo. Entre éstos, la cuenca del Sur de California (CSC) es un ecosistema marino altamente productivo del océano Pacífico nororiental (Steneck et al. 2002) (fig. 1), cuyos límites norte y sur se

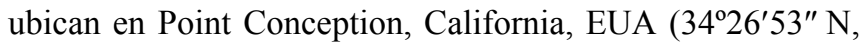
$120^{\circ} 28^{\prime} 17^{\prime \prime} \mathrm{W}$ ), y Punta Colonet, Baja California, México $\left(30^{\circ} 57^{\prime} 29^{\prime \prime} \mathrm{N}, 116^{\circ} 19^{\prime} 42^{\prime \prime} \mathrm{W}\right)$, respectivamente (Dailey et al. 1993). La región de la CSC tiene una larga historia de explotación humana (e.g., Erlandson y Torben 2010). La sobrepesca y caza excesiva han llevado a la eliminación de nutrias, a la extinción ecológica de varias especies de abulón y peces, y a la disminución de la abundancia de especies comerciales y recreativas (Dayton et al. 1998, Tegner y Dayton 2000). En consecuencia, la protección de las especies que permanecen es de suma importancia para la conservación y el manejo adecuado de este ecosistema valioso.

A lo largo de la CSC, el sargazo gigante Macrocystis pyrifera crece en densos bosques submareales y proporciona hábitats biogénicos que sostienen diversas comunidades biológicas e importantes especies pesqueras (Foster y Schiel 1985, Hernández-Carmona et al. 1989, Graham 2004, Parnell et al. 2010). La biomasa algal que se produce en estos bosques representa una importante fuente de alimento para muchas especies bentónicas y pelágicas locales, tanto dentro de los bosques como en los ambientes adyacentes (Bradley y Bradley 1993, Graham et al. 2007). Macrocystis pyrifera es frecuentemente considerada una especie fundadora $\mathrm{y} / \mathrm{o}$ ingeniero de ecosistemas con una estructura tridimensional que impide parcialmente o totalmente que la luz llegue al sustrato, reduce corrientes e incrementa la sedimentación (Dayton 1971, Jones et al. 1994, Gaylord et al. 2007). Estos bosques crecen en sustratos rocosos y someros $(<30 \mathrm{~m})$, donde presentan una distribución desigual (en parches) (Parnell et al. 2006) y se ven afectados por estresores ambientales como agua cálida pobre en nutrientes, fuerzas hidrodinámicas fuertes (e.g., oleaje) durante tormentas, una mayor sedimentación y cambios en la calidad del agua y el pastoreo por herbívoros (Ebeling et al. 1985; Tegner y Dayton 1987, 2000; Ladah et al. 1999; Edwards 2004; Foster y Schiel 2010). Por lo tanto, la distribución y abundancia de estos bosques pueden variar a diferentes escalas espaciales y temporales (e.g., Edwards 2004), lo cual dificulta las generalizaciones regionales.

Varios investigadores han proporcionado información sobre las comunidades de los bosques de macroalgas de California (e.g., Dayton 1985, Foster y Schiel 1985, Foster y Vanblaricom 2001), y tal información ha sido muy valiosa para el diseño de áreas marinas protegidas (AMPs) (e.g., Parnell et al. 2006; Pondella et al. 2011a, 2011b). En 
Throughout the SCB, the giant kelp Macrocystis pyrifera grows in dense subtidal forests and creates biogenic habitats that sustain diverse biological assemblages and important fishery species (Foster and Schiel 1985, Hernández-Carmona et al. 1989, Graham 2004, Parnell et al. 2010). Further, the kelp biomass produced in these forests is itself an important food source for many local benthic and pelagic species, both within the forests and the adjacent environments (Bradley and Bradley 1993, Graham et al. 2007). Macrocystis pyrifera is often considered a foundation species and/or ecosystem engineer with a three-dimensional structure that partially or completely blocks light from reaching the substratum, reduces currents, and increases sedimentation (Dayton 1971, Jones et al. 1994, Gaylord et al. 2007). These forests grow on shallow $(<30 \mathrm{~m})$ rocky substrates where they exhibit patchy distributions (Parnell et al. 2006), and are affected by environmental stressors such as warm nutrient-poor water, strong hydrodynamic forces (e.g., waves) during storms, increased sedimentation, and changes in water quality and herbivore grazing (Ebeling et al. 1985; Tegner and Dayton 1987, 2000; Ladah et al. 1999; Edwards 2004; Foster and Schiel 2010). Consequently, the distribution and abundance of these forests can vary across a number of spatial and temporal scales (e.g., Edwards 2004), often making regional generalizations difficult.

Several researchers have provided information on community structure of kelp forests from California (e.g., Dayton 1985, Foster and Schiel 1985, Foster and Vanblaricom 2001), and such information has proven invaluable to the informed design of Marine Protected Areas (MPAs) (e.g., Parnell et al. 2006; Pondella et al. 2011a, 2011b). In contrast, the relevant information on spatio-temporal patterns in kelp forest community structure from Mexico is comparatively lacking. Most of the existing information concerning Mexican kelp forest inhabitants is limited to isolated studies on algal groups (e.g., Hernández-Carmona et al. 1989, Ladah et al. 1999, Edwards and Hernández-Carmona 2005, Edwards and Estes 2006), fish species (e.g., Hammann and Rosales-Casián 1990, Pondella et al. 2005), or populations of commercially important species such as sea urchins (Palleiro-Nayar et al. 1996, Salgado-Rogel and Palleiro-Nayar 2008), abalones and lobsters (Guzmán del Próo et al. 2000, Arteaga-Ríos et al. 2007).

Species richness is frequently used as a conservation target for maintaining biodiversity, and higher richness habitats can be prioritized as potential conservation areas (e.g., Pressey et al. 1993). And, because morphologically heterogeneous environments have been found to support more diverse biological assemblages (McClain and Barry 2010, Kovalenko et al. 2012), the assessment of the relationship between heterogeneity and biodiversity has practical advantages for the design of MPAs or reserve networks (Roberts et al. 2003). For the benthic subtidal environment, however, most studies of such relationship have been focused on fish communities from coral reefs (e.g., Wilson et al. 2007). In contraste, hay escasa información relevante de los patrones espaciotemporales de la estructura de la comunidad de los bosques de macroalgas de México. La mayor parte de la información disponible sobre los habitantes de estos bosques consiste de estudios aislados de grupos de algas (e.g., Hernández-Carmona et al. 1989, Ladah et al. 1999, Edwards y Hernández-Carmona 2005, Edwards y Estes 2006), especies ícticas (e.g., Hammann y Rosales-Casián 1990, Pondella et al. 2005), y poblaciones de especies comerciales importantes como el erizo de mar (Palleiro-Nayar et al. 1996, Salgado-Rogel y Palleiro-Nayar 2008), el abulón y la langosta (Guzmán del Próo et al. 2000, Arteaga-Ríos et al. 2007).

La riqueza de especies se utiliza con frecuencia como un objetivo de conservación para mantener la biodiversidad, y se pueden priorizar los hábitats con mayor riqueza como zonas de conservación potenciales (e.g., Pressey et al. 1993). Además, considerando que los ambientes morfológicamente heterogéneos mantienen comunidades biológicas más diversas (McClain y Barry 2010, Kovalenko et al. 2012), la evaluación de la relación entre la heterogeneidad y la biodiversidad tiene ventajas prácticas para el diseño de las AMPs o redes de reservas (Roberts et al. 2003). En el caso de los ambientes bentónicos submareales, la mayoría de los trabajos de tal relación se han enfocado en comunidades ícticas de arrecifes coralinos (e.g., Wilson et al. 2007). En los sistemas de bosques de macroalgas, se han estudiado las relaciones entre el manto algal, la luz y la sedimentación con los conjuntos algales del sotobosque (e.g., Connell 2003, Clark et al. 2004), entre las macroalgas y el reclutamiento de invertebrados bentónicos (Duggins et al. 1990), y entre la complejidad topográfica (rugosidad) y la estructura de la comunidad de algas (e.g., Fowler-Walker y Connell 2007, Toohey et al. 2007). Así, ampliar los estudios de la estructura de la comunidad de los bosques de macroalgas de la CSC y de la relación entre la heterogeneidad y la diversidad proporcionará información de un factor regulador potencial de la diversidad biológica que pudiera usarse en el futuro como un criterio adicional para el diseño de las AMPs. Por lo tanto, el objetivo de este trabajo fue caracterizar la variabilidad espacial y temporal de las comunidades bentónicas marinas dentro de un grupo de bosques de macroalgas que se distribuyen a lo largo de la región fronteriza de la CSC que comparten México y los Estados Unidos, así como examinar la relación entre un índice de heterogeneidad de hábitat y la diversidad biológica de estos hábitats.

\section{MATERIALES Y MÉTODOS}

Se escogieron cinco bosques de macroalgas cubriendo una distancia geográfica de ca $195 \mathrm{~km}$ dentro de la CSC y a lo largo de las costas de California (EUA) y Baja California (México) para representar un grupo transfronterizo de sitios y comparar los patrones espaciales y temporales de la estructura de la comunidad. Tres de los bosques se localizaron en la 
kelp forest systems, studies have recorded relationships of kelp canopy, light, and sedimentation with understory algal assemblages (e.g., Connell 2003, Clark et al. 2004), between kelps and recruitment of benthic invertebrates (Duggins et al. 1990), and between topographic complexity (rugosity) and algal assemblage structure (e.g., Fowler-Walker and Connell 2007, Toohey et al. 2007). Therefore, expanding community structure studies of kelp forests from the SCB and of the relationship between heterogeneity and diversity will give insight of a potential driving factor of biological diversity that could be used in the future as an additional criteria for the design of MPAs. In consequence, the objective of this study was to characterize the spatial and temporal variability of marine benthic assemblages within a group of kelp forests that are distributed along the shared SCB border region of Mexico and the United States, and to test the relationship between a habitat heterogeneity index and the biological diversity of these habitats.

\section{MATERIALS AND METHODS}

Five kelp forests spanning a geographic distance of $c a$ $195 \mathrm{~km}$ within the SCB and along the California (USA) and Baja California (Mexico) coasts were chosen to represent a transboundary group of sites for comparing spatial and temporal patterns in community structure. Three of the kelp forests were located along the Mexican coastline and two along the United States coastline. One of these two sites was located in the San Diego-La Jolla Ecological Reserve that was established in 1971 (fig. 1). Kelp forests were selected based on three criteria: (1) they had persistent kelp canopies, (2) they occurred below the "shallow zone" limit of $9 \mathrm{~m}$ (sensu Foster and Vanblaricom 2001), and (3) they all occurred in the Southern Ensenadian Biogeographical Province (Blanchette et al. 2008), so that differences caused by latitudinal species substitutions could be assumed negligible.

Within each kelp forest, temporal variability in benthic community composition was estimated using non-destructive diving expeditions during June and July of 2007, 2008, and 2010 with the support of local fishermen. Sampling was not done in 2009 because it was the beginning of an El Niño and access to the sites was limited due to large waves. Specifically, within each forest, three $10-\mathrm{m}$ transects were run along the benthos, starting from the kelp forest's center and radiating out along randomly generated compass headings for every year. The center of the site was determined using GPS so that it could be relocated and resampled in subsequent years. The abundances of all macrofauna and macroflora were estimated by taking photographs of the benthic assemblages every meter on each side of the transect using a $0.25 \mathrm{~m}^{2}$ frame. The sampling effort needed to obtain reliable estimates of species richness was determined using the species accumulation curve defined by the average number of species under all possible permutations of samples (Ugland et al. 2003, Bakus 2007). Preliminary survey data were costa de México y dos en la costa de los Estados Unidos. Uno de estos dos sitios se localizó en la Reserva Ecológica de San Diego-La Jolla establecida en 1971 (fig. 1). Los bosques de macroalgas se seleccionaron con base en tres criterios: (1) que tuvieran mantos de macroalgas persistentes, (2) que estuvieran por debajo del límite de la "zona somera" de $9 \mathrm{~m}$ (sensu Foster y Vanblaricom 2001), y (3) que estuvieran en la Provincia Biogeográfica Sudensenadense (Blanchette et al. 2008), para que las diferencias causadas por sustituciones de especies latitudinales pudieran considerarse insignificantes.

Dentro de cada bosque de macroalgas se estimó la variabilidad temporal de la composición de la comunidad bentónica mediante campañas de buceo no destructivo en junio y julio de 2007, 2008 y 2010, con el apoyo de pescadores locales. No se realizaron muestreos en 2009 porque iniciaba un evento El Niño y olas grandes limitaron el acceso a los sitios. Específicamente, dentro de cada bosque, cada año se recorrieron tres transectos de $10 \mathrm{~m}$ en el fondo, comenzando en el centro del bosque y procediendo hacia fuera en tres rumbos aleatorios marcados por la brújula. El centro del sitio se determinó mediante GPS para que pudiera ser relocalizado y remuestreado en años subsecuentes. Para estimar la abundancia de toda la macrofauna y macroflora, se tomaron fotografías de los conjuntos bentónicos en cada metro y en cada lado del transecto usando un cuadrante de $0.25 \mathrm{~m}^{2}$. El esfuerzo de muestreo necesario para obtener estimaciones confiables de la riqueza de especies se determinó usando la curva de acumulación de especies definida por el número promedio de especies bajo todas las permutaciones de las muestras (Ugland et al. 2003, Bakus 2007). Se obtuvieron datos preliminares de los cinco sitios en 2007, y se determinó que era necesario un tamaño de muestreo mínimo de 23 cuadrantes; sin embargo, considerando que el patrón de acumulación de especies puede variar de año a año, escogimos un esfuerzo más conservador (30 muestras) para cada campaña.

En el laboratorio, se examinaron las fotografías y se determinó la densidad y/o el porcentaje de cobertura de cada especie o nivel taxonómico mayor. Para reducir la influencia de usar diferentes tipos de mediciones (i.e., porcentaje de cobertura vs conteos individuales), los datos fueron estandarizados y transformados con raíz cuadrada (Clarke y Gorley 2006). Para mostrar la variabilidad espacial y temporal de las similitudes de la comunidad bentónica, se generaron gráficas de escalamiento multidimensional no métrico para cada año con base en índices de similitud de Bray-Curtis entre transectos. Posteriormente, se realizó un análisis de varianza multivariado con base en permutaciones (PERMANOVA) de dos vías para evaluar la variación de la estructura de la comunidad entre años y sitios. Para determinar la cantidad de variación de la composición de la comunidad atribuida a las diferencias entre sitios, años y transectos, se calculó la magnitud del efecto asociado con cada factor (Graham y Edwards 2001). Se usó la rutina BVSTEP para identificar el subconjunto más pequeño de especies capaces de reproducir las diferencias observadas en la similitud de la comunidad 
obtained from the five sites during 2007, and a minimum sampling size of 23 quadrants was determined necessary. However, because we recognize that the species accumulation pattern may vary from year to year, we chose a more conservative effort (30 samples) for every survey.

In the laboratory, the photographs were examined and the density and/or percentage cover was determined for each species or higher taxonomic level. To reduce the influence of using different types of measurements (i.e., \% cover vs individual counts), data were standardized and square root transformed (Clarke and Gorley 2006). To illustrate the spatial and temporal variability in benthic community similarities, multivariate non-metric multidimensional scaling (nMDS) plots were generated for each year based on between-transect Bray-Curtis similarity indices. Following this, variation in community structure among years and sites was statistically examined using a two-way Permutational Multivariate Analysis of Variance (PERMANOVA). To determine the amount of variation in community composition that was due to differences among sites, years, and transects, we calculated the magnitude of effect associated with each factor (Graham and Edwards 2001). We then used the BVSTEP routine to identify the smallest subset of species capable of reproducing the observed differences in community similarity ( $\mathrm{rho}=0.95$ and 100 permutations). To further examine the relative importance of individual species in relation to the observed differences in community structure, a two-way similarity percentage (SIMPER) analysis was performed. To test if the differences in community composition among sites were related to the geographic distance between them, we used independent correlations among the geographic distance and the pair-wise Bray-Curtis dissimilarity between sites for each year.

To assess the relationship between habitat heterogeneity and biological diversity, we calculated a modified substratum rugosity index (RI, Luckhurst and Luckhurst 1978) for each site during the 2010 expedition. At each site, depth was recorded at every meter along each transect using a Suunto Vyper dive computer. Profiles were later graphed and the substratum RI was calculated by dividing the total profile length by the fixed $10-\mathrm{m}$ transect distance. To examine the overall relationship between substratum rugosity and species richness, and since we did not expect the substrate geomorphology (i.e., each site's RI) to change significantly during the time frame of our study, we used a regression analysis between both variables for the three years of study. PRIMER 6.1.11 (Clarke and Gorley 2006) was used to perform the multivariate analyses, and all the univariate analyses were done with SYSTAT ver. 13 (SYSTAT 2009).

\section{RESULTS}

More than $50 \%$ of all the taxa found during the three years appeared in at least four of the five sites and no identifiable latitudinal patterns of species substitution were observed (rho $=0.95$ y 100 permutaciones). Para examinar más a fondo la importancia relativa de las especies individuales en relación con las diferencias observadas en la estructura de la comunidad, se realizó un análisis de porcentajes de similitud (SIMPER) de dos vías. Para comprobar si las diferencias en la composición de la comunidad entre sitios estaban relacionadas con la distancia geográfica entre ellos, se usaron correlaciones independientes entre la distancia geográfica y la disimilitud de Bray-Curtis de pares de sitios para cada año.

Para evaluar la relación entre la heterogeneidad de hábitat y la diversidad biológica, se calculó un índice de rugosidad (IR) del sustrato modificado (Luckhurst y Luckhurst 1978) para cada sitio durante la campaña de 2010. En cada sitio se registró la profundidad a cada metro a lo largo del transecto con un ordenador de buceo Suunto Vyper. Los perfiles fueron graficados y el IR del sustrato fue calculado dividiendo la longitud total del perfil por la distancia fija del transecto de $10 \mathrm{~m}$. Para determinar la relación general entre la rugosidad del sustrato y la riqueza de especies, y suponiendo que la geomorfología del sustrato (i.e., IR de cada sitio) no cambiaría significativamente durante el marco temporal del estudio, se usó un análisis de regresión entre ambas variables para los tres años de estudio. Los análisis multivariados se realizaron con el programa PRIMER 6.1.11 (Clarke y Gorley 2006) y los análisis univariados con SYSTAT ver. 13 (SYSTAT 2009).

\section{REsultados}

Más del $50 \%$ de todos los taxones encontrados durante los tres años de estudio aparecieron en al menos cuatro de los cinco sitios y no se observaron patrones latitudinales identificables de la sustitución de especies (tabla 1). La composición de la comunidad varió significativamente entre los cinco bosques de macroalgas (PERMANOVA: $P=0.0026$ ), pero no entre los tres años $(P=0.2568$, tabla 2$)$. Asimismo, las diferencias relativas entre los cinco bosques variaron entre los tres años (interacción sitio $\times$ año $P<0.001$ ), lo que sugiere que además de las diferencias entre los bosques de macroalgas, los cambios temporales en las abundancias relativas de las diferentes especies no fueron consistentes entre los bosques. A pesar de que tales efectos de interacción son difíciles de visualizar, las gráficas de escalamiento multidimensional no métrico (fig. 2) muestran que las diferencias entre sitios (según el método de clasificación jerárquica) no fueron iguales en años diferentes. La figura 2 también muestra menor variación dentro de los sitios registrada a partir de los transectos en comparación con mayores diferencias observadas entre los sitios durante cada año de estudio. De hecho, la variabilidad entre sitios explicó $40 \%$ de la variación total de la composición de la comunidad, mientras que la variabilidad entre transectos dentro de cada sitio explicó $16 \%$ de la variación total. La variabilidad entre los años de estudio representó sólo $\sim 3 \%$ de la variación total, y la variabilidad debida a la interacción entre años y sitios representó $41 \%$ de 
(table 1). The community composition varied significantly among the five kelp forest sites (PERMANOVA: $P=$ $0.0026)$, but not between the three sampled years $(P=$ 0.2568 , table 2). Further, the relative differences among the five kelp forests varied among the three years (site $\times$ year interaction $P<0.001$ ) suggesting that in addition to the differences among kelp forests, temporal changes in the relative abundances of the different species were not consistent among kelp forests. Although such interaction effects are difficult to visualize, the nMDS plots (fig. 2) illustrate that la variación (tabla 2). En conjunto, esto indica que la mayor parte de la variabilidad (81\%) se debió a diferencias entre los bosques de macroalgas o a diferencias en cómo los cinco bosques variaron a través del tiempo. La rutina BVSTEP mostró que un subconjunto de cinco taxones, incluyendo algas rojas foliáceas, algas coralinas geniculadas y no geniculadas (Corallina sp. y Lithothamnion sp.), el coral Balanophyllia elegans y el erizo morado Strongylocentrotus purpuratus, podría explicar el $95 \%$ de la variación de la composición de la comunidad (correlación $=0.95$ ). El análisis SIMPER de

Table 1. Total counts (number $/ 45 \mathrm{~m}^{2}$ ) and average percentage cover of individual taxa observed within five kelp forests of the Southern California Bight during the three years of study.

Tabla 1. Conteos totales (número/45 $\mathrm{m}^{2}$ ) y porcentaje de cobertura promedio de los taxones individuales observados en cinco bosques de macroalgas de la cuenca del Sur de California durante los tres años de estudio.

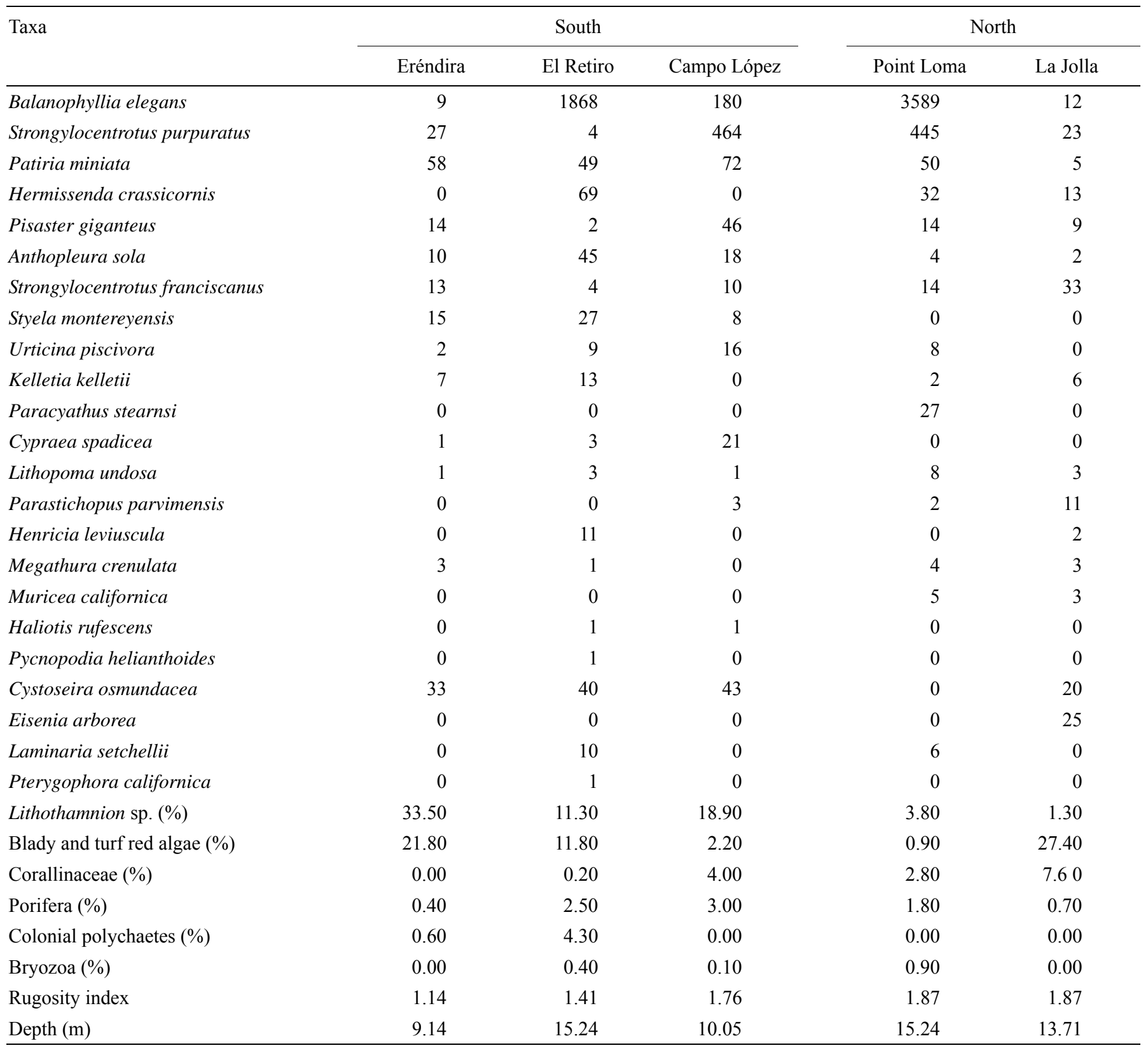


Table 2. Results of a two-way PERMANOVA testing differences in kelp forest benthic assemblages among the five kelp forest sites and three years of the study, and the magnitude of effect (ME) associated with each factor.

Tabla 2. Resultados de un PERMANOVA de dos vías probando diferencias de los conjuntos bentónicos en los bosques de macroalgas entre los cinco sitios de muestreo y los tres años de estudio, y la magnitud del efecto (ME) asociada con cada factor.

\begin{tabular}{lrrrrrr}
\hline Source & d.f. & \multicolumn{1}{c}{ SS } & MS & Pseudo- $F$ & $P($ perm. $)$ & ME $(\%)$ \\
\hline Sites & 4 & 41841.0 & 10460.00 & 3.5933 & 0.0026 & 40 \\
Years & 2 & 7643.4 & 3821.70 & 1.3128 & 0.2568 & 0.0001 \\
Sites $\times$ years & 8 & 23288.0 & 2911.00 & 8.6805 & 41 \\
Res & 30 & 10061.0 & 335.35 & & 16 \\
Transects & & & & & \\
\hline
\end{tabular}

differences between sites (judged by the ranking method) were not the same in different years. This same figure shows lower within-site variation registered from the three transects, compared with the higher between-site differences observed during each year of study. In fact, variability among study sites accounted for $40 \%$ of the total variation in community composition, while variability among transects within each site accounted for $16 \%$ of the total variation. Variability among sampled years accounted for only about $3 \%$ of the total variation, and variability due to the interaction between years and sites accounted for $41 \%$ of the variation (table 2). Together, this indicates that most variability (81\%) was attributed to either differences among kelp forests or to differences in how the five kelp forests varied over time. The BVSTEP routine revealed that a subset of five taxa that included foliose red algae, geniculate and non-geniculate coralline algae (Corallina sp. and Lithothamnion sp.), cup corals (Balanophyllia elegans), and purple sea urchins (Strongylocentrotus purpuratus) could explain 95\% of the variation in community compositions (correlation $=0.95$ ). Further, the two-way SIMPER analysis identified the same subset of species as the most relevant taxa that discriminated between years (table 3). Among them, foliose red algae abundances declined and $S$. purpuratus abundances increased at most sites during the study. Abalones were rarely seen and the lowest densities of some commercial fishery target species (S. franciscanus, Lithopoma undosa, Parastichopus parvimensis, and Megathura crenulata) were registered at the Mexican sites. No significant relationship was observed between geographic distance and the observed dissimilarity in community structure between kelp forests $(P=0.377)$. However, species richness was significantly related to substratum rugosity within each site $\left(R^{2}=0.357, P=0.019\right.$; fig. 3). The lowest substratum rugosity and species richness values were recorded at Eréndira and increased towards El Retiro, Campo López, La Jolla, and Point Loma.

\section{DISCUSSION}

Spatial and temporal variation in kelp forest community structure is frequently driven by environmental stressors such as natural disturbances, anthropogenic pollution, human
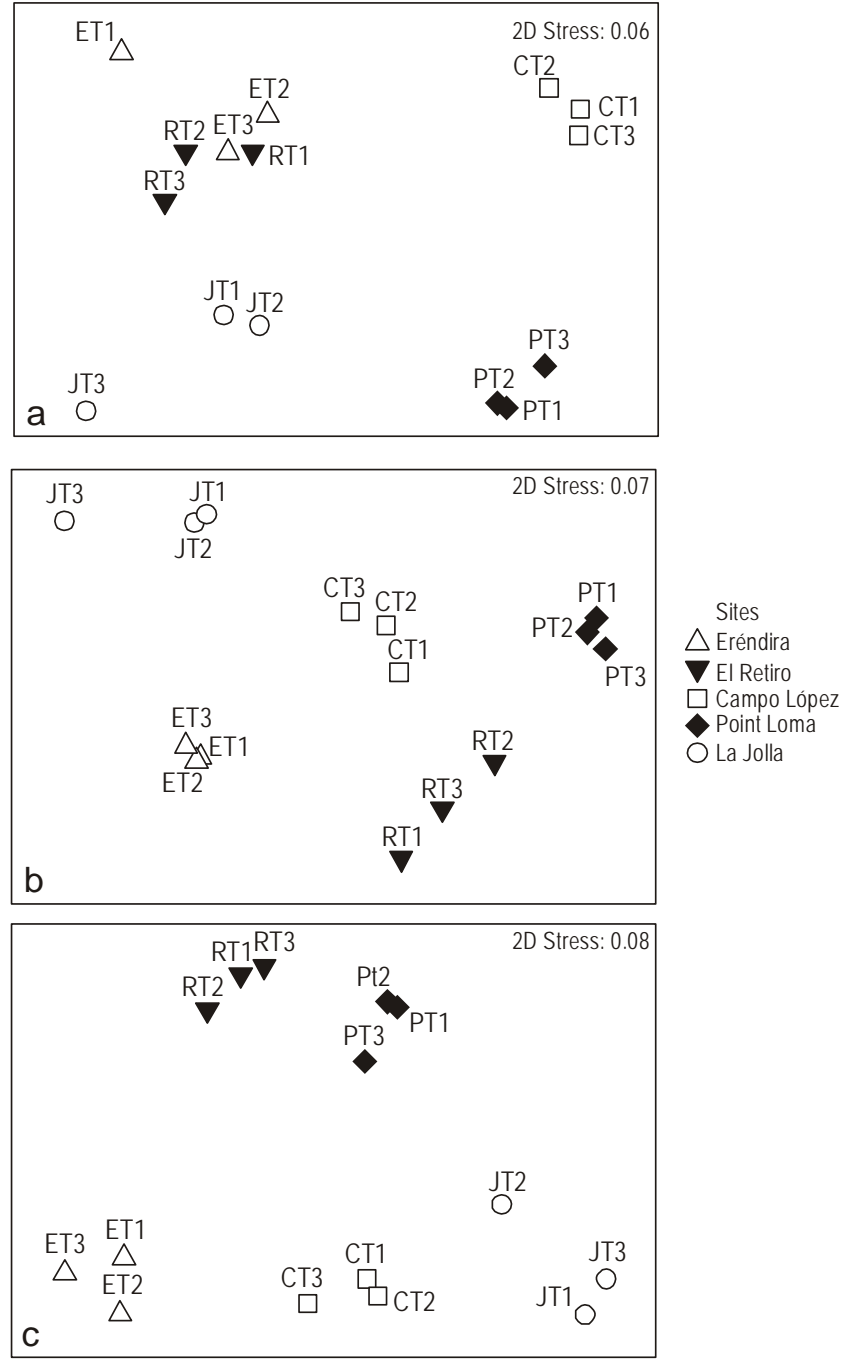

Figure 2. Spatial comparisons of kelp forest transects using nonmetric multidimensional scaling plots based on Bray-Curtis similarity indices during (a) 2007, (b) 2008, and (c) 2010. Sites and transect numbers are noted.

Figura 2. Comparaciones espaciales de los transectos en los bosques de macroalgas usando gráficas de escalamiento multidimensional no métrico con base en los índices de similitud de Bray-Curtis durante (a) 2007, (b) 2008 y (c) 2010. Los sitios y los números de transecto aparecen indicados. 
Table 3. Two-way SIMPER analysis list of the species that discriminate between the years 2007 and 2008, 2007 and 2010 , and 2008 and 2010 irrespective of kelp forest site (cut-off percentage of 90\%).

Tabla 3. Lista de especies, obtenida del análisis SIMPER de dos vías, que discriminan entre los años 2007 y 2008 , 2007 y 2010 , y 2008 y 2010 independientemente del sitio de bosque de macroalgas (porcentaje de corte de $90 \%$ ).

\begin{tabular}{|c|c|c|c|c|c|c|}
\hline \multirow[t]{2}{*}{ Taxon } & Av. Abund. & Av. Abund. & Av. Diss. & Diss./SD & Contrib. \% & \multirow[t]{2}{*}{ Cum. $\%$} \\
\hline & \multicolumn{5}{|c|}{2007 vs 2008} & \\
\hline Blady and turf red algae (\%) & 8.02 & 6.15 & 9.56 & 1.11 & 22.27 & 22.27 \\
\hline Lithothamnion sp. (\%) & 5.00 & 6.75 & 4.93 & 1.09 & 11.48 & 33.75 \\
\hline Balanophyllia elegans & 5.10 & 4.77 & 3.65 & 0.88 & 8.51 & 42.26 \\
\hline Corallinaceae (\%) & 3.11 & 2.96 & 3.49 & 0.99 & 8.14 & 50.40 \\
\hline Cystoseira sp. & 1.40 & 0.75 & 3.37 & 1.01 & 7.84 & 58.25 \\
\hline Porifera (\%) & 1.72 & 2.79 & 3.24 & 1.05 & 7.55 & 65.80 \\
\hline Patiria miniata & 2.25 & 1.42 & 1.81 & 1.48 & 4.22 & 70.02 \\
\hline Bryozoa (\%) & 0.13 & 1.06 & 1.57 & 0.90 & 3.66 & 73.69 \\
\hline Styela montereyensis & 0.87 & 0.48 & 1.26 & 0.69 & 2.93 & 76.62 \\
\hline Anthopleura sola & 0.83 & 0.48 & 1.26 & 1.10 & 2.93 & 79.55 \\
\hline Pisaster giganteus & 0.60 & 0.83 & 1.24 & 1.09 & 2.90 & 82.44 \\
\hline Strongylocentrotus purpuratus & 1.36 & 1.75 & 1.04 & 0.70 & 2.43 & 84.87 \\
\hline Strongylocentrotus franciscanus & 0.09 & 0.67 & 0.95 & 0.74 & 2.22 & 87.09 \\
\hline Lithopoma undosa & 0.37 & 0.43 & 0.77 & 0.88 & 1.80 & 88.88 \\
\hline \multirow[t]{2}{*}{ Kelletia kelletii } & 0.32 & 0.23 & 0.68 & 0.69 & 1.59 & 90.48 \\
\hline & \multicolumn{6}{|c|}{2007 vs 2010} \\
\hline Blady and turf red algae (\%) & 8.02 & 2.69 & 9.97 & 1.19 & 17.00 & 17.00 \\
\hline Balanophyllia elegans & 5.10 & 10.26 & 9.23 & 1.01 & 15.74 & 32.74 \\
\hline Lithothamnion sp. (\%) & 5.00 & 8.09 & 8.60 & 0.78 & 14.65 & 47.39 \\
\hline Strongylocentrotus purpuratus & 1.36 & 4.93 & 5.07 & 0.90 & 8.65 & 56.04 \\
\hline Corallinaceae (\%) & 3.11 & 1.58 & 3.23 & 0.96 & 5.51 & 61.55 \\
\hline Porifera (\%) & 1.72 & 2.55 & 2.37 & 1.53 & 4.05 & 65.60 \\
\hline Colonial polychaetes (\%) & 0.00 & 1.94 & 2.36 & 0.59 & 4.03 & 69.62 \\
\hline Hermissenda crassicornis & 0.16 & 1.88 & 1.96 & 0.99 & 3.34 & 72.96 \\
\hline Cystoseira sp. & 1.40 & 0.00 & 1.93 & 0.67 & 3.29 & 76.24 \\
\hline Pisaster giganteus & 0.60 & 1.51 & 1.59 & 1.22 & 2.70 & 78.94 \\
\hline Strongylocentrotus franciscanus & 0.09 & 1.06 & 1.46 & 0.67 & 2.48 & 81.43 \\
\hline Patiria miniata & 2.25 & 2.17 & 1.33 & 1.45 & 2.27 & 83.70 \\
\hline Styela montereyensis & 0.87 & 0.42 & 1.25 & 0.96 & 2.13 & 85.82 \\
\hline Anthopleura sola & 0.83 & 1.36 & 1.12 & 1.03 & 1.91 & 87.73 \\
\hline Urticina piscivora & 0.23 & 0.72 & 1.05 & 0.95 & 1.79 & 89.52 \\
\hline Kelletia kelletii & 0.32 & 0.76 & 0.96 & 0.87 & 1.64 & 91.17 \\
\hline
\end{tabular}


Table 3 (Cont.)

\begin{tabular}{|c|c|c|c|c|c|c|}
\hline \multirow[t]{2}{*}{ Taxon } & \multirow[t]{2}{*}{ Av. Abund. } & Av. Abund. & Av. Diss. & Diss./SD & Contrib. \% & \multirow[t]{2}{*}{ Cum. \% } \\
\hline & & \multicolumn{4}{|c|}{2008 vs 2010} & \\
\hline Blady and turf red algae (\%) & 6.15 & 2.69 & 6.58 & 0.75 & 13.94 & 29.51 \\
\hline Lithothamnion sp. (\%) & 6.75 & 8.09 & 6.54 & 0.95 & 13.86 & 43.37 \\
\hline Corallinaceae $(\%)$ & 2.96 & 1.58 & 2.41 & 0.74 & 5.11 & 58.44 \\
\hline Colonial polychaetes $(\%)$ & 0.00 & 1.94 & 2.31 & 0.59 & 4.89 & 63.33 \\
\hline Hermissenda crassicornis & 0.00 & 1.88 & 2.26 & 1.04 & 4.79 & 68.11 \\
\hline Porifera $(\%)$ & 2.79 & 2.55 & 1.90 & 1.76 & 4.03 & 72.14 \\
\hline Patiria miniata & 1.42 & 2.17 & 1.16 & 1.16 & 2.47 & 81.37 \\
\hline Pisaster giganteus & 0.83 & 1.51 & 1.05 & 1.02 & 2.22 & 83.59 \\
\hline Urticina piscivora & 0.38 & 0.72 & 1.04 & 1.08 & 2.21 & 85.80 \\
\hline Cystoseira sp. & 0.75 & 0.00 & 0.92 & 0.49 & 1.94 & 87.74 \\
\hline Kelletia kelletii & 0.23 & 0.76 & 0.90 & 0.79 & 1.91 & 89.65 \\
\hline Parastichopus parvimensis & 0.07 & 0.38 & 0.76 & 0.48 & 1.60 & 91.25 \\
\hline
\end{tabular}

exploitation, and variability in temperature, nutrients, and irradiance, and/or by biological interactions such as competition, predation, and grazing (Dayton et al. 1984, 1998; Ebeling et al. 1985; Foster and Vanblaricom 2001; Foster and Schiel 2010; Parnell et al. 2010; Watson et al. 2011). Kelp forests, however, are resilient habitats that are continuously exposed to high frequency disturbances such as winter storms and to low frequency disturbances such as El Niño Southern Oscillations, which operate on different spatial and temporal scales, suggesting that patterns of variability may similarly occur at a variety of spatial and temporal scales (e.g., Edwards 2004). Consequently, to fully evaluate patterns of variability in kelp forests in the SCB region, several forests need to be studied over a sufficiently long period to capture their temporal trajectories.

In this study we have shown that while benthic marine communities occurring in five kelp forests that span the SCB region share some species, they are significantly different from each other and their temporal changes were not consistent across all forests. The presence of shared species and the absence of latitudinal species substitutions may be explained by the fact that these communities belong to the same biogeographical region (the Southern Ensenadian Biogeographical Province) and, therefore, likely experience similar environmental features. Other authors have reported latitudinal species substitutions between sites in some northern Californian regions of the SCB with similar geographic distances to this dos vías identificó el mismo subconjunto de especies como los taxones más relevantes que discriminaron entre años (tabla 3). Entre ellos, la abundancia de algas rojas foliosas disminuyó y la abundancia de $S$. purpuratus aumentó en la mayoría de los sitios durante el estudio. Raramente se observaron abulones y las densidades más bajas de algunas especies capturadas por pesquerías comerciales (S. franciscanus, Lithopoma undosa, Parastichopus parvimensis y Megathura crenulata) se registraron en los sitios mexicanos. No se observó una relación significativa entre la distancia geográfica y la disimilitud en la estructura de la comunidad entre los bosques de macroalgas $(P=0.377)$; sin embargo, se observó una relación significativa entre la riqueza de especies y la rugosidad del sustrato en cada sitio $\left(R^{2}=0.357, P=0.019\right.$; fig. 3). Los valores de la riqueza de especies y rugosidad del sustrato fueron menores en Eréndira e incrementaron hacia El Retiro, Campo López, La Jolla y Point Loma.

\section{DISCUSIÓN}

La variación espacial y temporal de la estructura de la comunidad de bosques de macroalgas es comúnmente regida por estresores ambientales tales como disturbios naturales, contaminación antropogénica, explotación humana, y variaciones de temperatura, nutrientes e irradiación, y/o por interacciones biológicas como competencia, depredación y pastoreo (Dayton et al. 1984, 1998; Ebeling et al. 1985; 


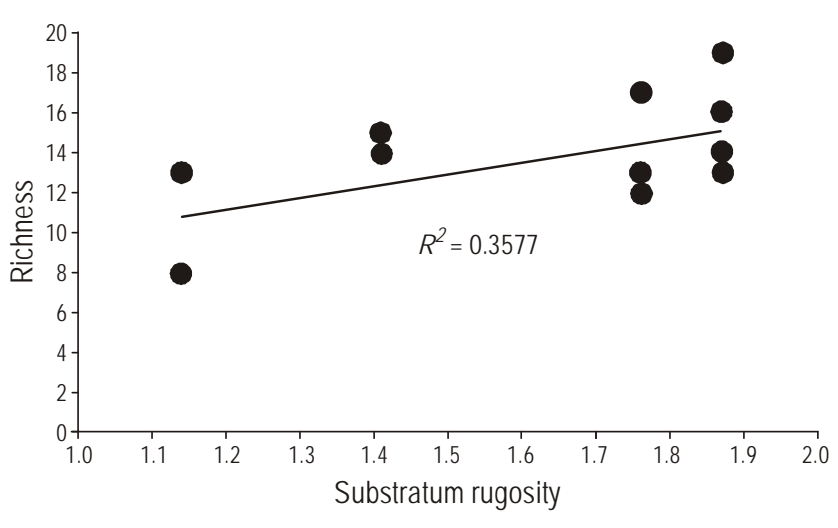

Figure 3. Relationship between the substratum rugosity of the mainland kelp forests and their benthic species richness (significant with $P=0.019$ ). Substratum rugosity was registered during 2010.

Figura 3. Relación entre la rugosidad del sustrato de los bosques de macroalgas y su riqueza de especies bentónicas (significativo con $P=0.019$ ). La rugosidad del sustrato (índice de rugosidad) se registró en 2010.

study but with large variation in temperature (e.g., Watson et al. 2011). In contrast, the sampled sites from the transboundary SCB region share similar average seasonal ocean temperatures (Durazo et al. 2010) and mesoscale north-south shifting currents (Di Lorenzo 2003), which may control historical transboundary pelagic larval mixing and recruitment of benthic species that inhabit the kelp forest habitats.

Even though different kelp forests share species on a regional scale, the geographic distance between them or the variability in habitat quality may explain the spatial changes in their community structure. We tested whether geographic distance between sites or changes in substratum rugosity were related to the observed spatial differences in community similarity or species richness, respectively. While geographic distance has been used to explain latitudinal changes in rocky intertidal communities in a more extensive latitudinal comparison including the SCB (Blanchette et al. 2008), our results failed to reveal a significant relationship between geographic distance and the community similarity of studied sites. In contrast, local variation in substratum rugosity was positively and significantly related to the kelp forest benthic species richness. The "habitat heterogeneity hypothesis" supports the idea that spatially heterogeneous environments sustain higher species richness and the prevailing explanation assumes that more niches are available in structurally complex environments (Tews et al. 2004, Kovalenko et al. 2012). The importance of heterogeneity as a precursor to biological diversity has led some authors to suggest that the protection and enhancement of heterogeneity should be an important basis for the conservation and management of ecological communities (Fuhlendorf et al. 2006). Our results agree with this idea for the benthic kelp forest communities and emphasize the importance of further testing this and similar approaches of habitat complexity in other kelp forest
Foster y Vanblaricom 2001; Foster y Schiel 2010; Parnell et al. 2010; Watson et al. 2011). No obstante, los bosques de macroalgas son hábitats resilientes, continuamente expuestos a perturbaciones de alta frecuencia como tormentas invernales y a perturbaciones de baja frecuencia como El Niño/ Oscilación del Sur, que operan a diferentes escalas espaciales y temporales; esto sugiere que los patrones de variabilidad también pueden operar a diversas escalas espaciales y temporales (e.g., Edwards 2004). Por ende, para evaluar plenamente los patrones de variabilidad en los bosques de macroalgas de la región de la CSC, es necesario estudiar varios bosques durante un periodo de tiempo suficientemente largo para capturar sus trayectorias temporales.

En este trabajo hemos mostrado que a pesar de que las comunidades marinas bentónicas que se encuentran en cinco bosques de macroalgas a lo largo de la región transfronteriza de la CSC comparten algunas especies, son significativamente diferentes entre ellas y los cambios temporales no fueron consistentes en todos los bosques. La presencia de especies compartidas y la ausencia de sustituciones de especies latitudinales pueden explicarse por el hecho de que estas comunidades pertenecen a la misma región biogeográfica (Provincia Biogeográfica Sudensenadense) y, por lo tanto, probablemente experimentan condiciones ambientales similares. Otros autores han documentado sustituciones de especies latitudinales entre sitios en algunas regiones del norte de California de la CSC con distancias geográficas similares a las de este estudio pero con una gran variación de temperatura (e.g., Watson et al. 2011). En contraste, los sitios muestreados en la región transfronteriza de la CSC comparten temperaturas estacionales promedio del mar similares (Durazo et al. 2010) y corrientes de mesoescala cambiantes hacia el norte o el sur (Di Lorenzo 2003), que pueden controlar la mezcla histórica transfronteriza de larvas pelágicas y el reclutamiento de especies bentónicas que habitan en los bosques de macroalgas.

Aunque diferentes bosques de macroalgas comparten especies a escala regional, la distancia geográfica entre ellos o la variabilidad de la calidad del hábitat pueden explicar los cambios espaciales en su estructura de la comunidad. Se analizó si la distancia geográfica entre sitios o los cambios en la rugosidad del sustrato estaban relacionados con las diferencias espaciales observadas en la similitud de la comunidad o la riqueza de especies, respectivamente. La distancia geográfica ha sido usada para explicar cambios latitudinales de comunidades del intermareal rocoso en una comparación latitudinal más extensa que incluyó la CSC (Blanchette et al. 2008); sin embargo, nuestros resultados no mostraron una relación significativa entre la distancia geográfica y la similitud de la comunidad en los sitios estudiados. En contraste, la variación local de la rugosidad del sustrato se relacionó positivamente y significativamente con la riqueza de las especies bentónicas de los bosques de macroalgas. La "hipótesis de la heterogeneidad del hábitat" sustenta la idea que los ambientes espacialmente heterogéneos mantienen una mayor riqueza de especies y la explicación prevaleciente supone que 
environments and with the demersal and pelagic fish communities.

Fishing activities may also directly impact the spatial and temporal changes in abundance of the observed commercial target species. At the studied sites, overfishing has significantly reduced abalone densities, and the lower abundance values of the fished species Strongylocentrotus franciscanus, Lithopoma undosa, and Megathura crenulata at the Mexican sites could be explained by a lower law enforcement and higher fishing effort compared to La Jolla Reserve and Point Loma.

El Niño events can lead to significant changes in kelp forests from the SCB region (Tegner and Dayton 1987, Edwards and Estes 2006). Specifically, kelp forest dynamics has been reported to shift from local to regional control during El Niños, while recovery following them returns these ecosystems to local control (Edwards 2004). However, most analyses of community similarities are restricted to spatially static cases that do not account for temporal changes including El Niño dynamics (Watson et al. 2011), and rarely consider the entire benthic community responses. In this study, no significant temporal changes in the kelp forest benthic community were observed. So contrary to expectations based on previous El Niño events (e.g., Edwards and Estes 2006), kelp forest benthic community assemblages did not change significantly after the 2009-2010 El Niño with the exception of a few species. Such an unexpected community response may be explained by the fact that the 2009-2010 El Niño was not accompanied by the high temperature anomalies that prevail during typical El Niño events. Instead, this event was linked to the Modoki phenomenon, where warm sea surface temperature is focused in the central equatorial Pacific and not in the eastern Pacific (Barnard et al. 2011). Nonetheless, winter ocean waves during the 2009-2010 El Niño were anomalously strong in the study region and were similar to the last significant El Niño in 1997-1998 (Barnard et al. 2011). Such environmental forcing dislodged much of the giant kelp, increased sand abrasion along the bottom, and may have in part contributed to the overall reductions in foliose red algae, and forced the S. purpuratus populations out of crevices to seek food, as has been reported in other areas of California (e.g., Breda and Foster 1985, Ebeling et al. 1985).

Substratum rugosity seemed to be an important local environmental driver of spatial variation in biological diversity, which is one of the most important biological criteria used for prioritizing conservation sites (Roberts et al. 2003). Given the expense of direct subtidal observations and sampling, we propose that substratum rugosity could be used as a proxy for future benthic biological diversity estimations in these habitats. Kelp forests behaved as complex ecosystems with short-term temporal changes that were not consistent across sites even after being exposed to a moderate El Niño event (2009-2010). Such complexity requires continued learning about the temporal patterns of kelp forest environments and their expected responses to disturbance. If we are hay una mayor disponibilidad de nichos en ambientes estructuralmente complejos (Tews et al. 2004, Kovalenko et al. 2012). La importancia de la heterogeneidad como un precursor de la diversidad biológica ha llevado a algunos autores a sugerir que la protección y el aumento de la heterogeneidad debería ser una base importante para la conservación y el manejo de comunidades ecológicas (Fuhlendorf et al. 2006). Nuestros resultados concuerdan con esta idea para las comunidades bentónicas de los bosques de macroalgas y recalcan la importancia de seguir estudiando este y otros enfoques de la complejidad del hábitat en otros ambientes de bosques macroalgales y con las comunidades ícticas demersales y pelágicas.

Las actividades pesqueras también pueden impactar directamente los cambios espaciales y temporales en la abundancia de especies comerciales. En los sitios estudiados, la sobrepesca ha reducido significativamente las densidades de abulón. Además, las menores abundancias de las especies objetivo Strongylocentrotus franciscanus, Lithopoma undosa y Megathura crenulata en los sitios mexicanos podrían deberse a una menor vigilancia y mayor esfuerzo de pesca en comparación con la Reserva de La Jolla y Point Loma.

Los eventos de El Niño pueden generar cambios importantes en los bosques de macroalgas de la CSC (Tegner y Dayton 1987, Edwards y Estes 2006). Específicamente, se ha documentado que la dinámica de los bosques cambia de un control local a regional durante un evento de El Niño y que la recuperación al finalizar el evento regresa estos ecosistemas a un control local (Edwards 2004); sin embargo, la mayoría de los análisis de similitudes de la comunidad se restrigen a casos espacialmente estáticos que no contemplan cambios temporales, incluyendo la dinámica de un evento de El Niño (Watson et al. 2011), y raramente consideran las respuestas de toda la comunidad bentónica. En el presente estudio, no se observaron cambios temporales significativos en la comunidad bentónica de los bosques de macroalgas. Así que contrariamente a lo observado durante eventos previos de El Niño (e.g., Edwards y Estes 2006), con excepción de algunas cuantas especies, las comunidades bentónicas no cambiaron significativamente después de El Niño 2009-2010. Esta respuesta imprevista puede atribuirse a que El Niño 2009-2010 no presentó las anomalías térmicas altas que prevalecen durante los eventos típicos. Más bien, este evento se relacionó con el fenómeno Modoki, en el cual la temperatura superficial cálida del mar se ubica en el Pacífico central ecuatorial y no en el Pacífico oriental (Barnard et al. 2011). No obstante, el oleaje en el invierno durante El Niño 2009-2010 fue anómalamente fuerte y similar al del último El Niño importante en 1997-1998 (Barnard et al. 2011). Tal forzamiento ambiental desprendió muchas de las macroalgas, incrementó la abrasión de la arena en el fondo y pudo haber contribuido en parte a la disminución de las algas rojas foliosas, obligando a las poblaciones de $S$. purpuratus a salir de las grietas en busca de alimento, como ha sido observado en otras zonas de California (e.g., Breda y Foster 1985, Ebeling et al. 1985). 
to predict changes in these critical habitats, monitoring activities should be implemented to support future adaptive management programs. The Baja California kelp forests considered in this study are the southernmost representatives of the SCB region, where current-driven water exchange links them as a shared US-Mexico network. However, additional research is required to include the local changes in fish fauna, to study the connectivity level of these critical habitats, and to identify the geographical limits of the transboundary exchange zone using multiple target species. We propose that regional long-term conservation efforts should incorporate this ecological knowledge to support science-based decisions, binational coordination of policies, and coherent management practices including the design of transboundary conservation networks as spatial management tools for the protection, conservation, and/or restoration of the SCB ecosystem.

\section{ACKNOWLEDGMENTS}

We gratefully acknowledge the Consejo Nacional de Ciencia y Tecnología (CONACYT, Mexico) and UCMEXUS for the doctoral fellowship to GTM and the support from the San Diego State Univerity-University of California Davis Joint Doctoral Program in Ecology. We also thank Todd Anderson and Rick Grosberg for their review and comments on this manuscript.

\section{REFERENCES}

Arteaga-Ríos LD, Carrillo-Laguna J, Belmar-Perez J, Guzmán del Próo SD. 2007. Postlarval settlement of California spiny lobster Panulirus interruptus in Bahia Tortugas, Baja California and its relationship to the commercial catch. Fish. Res. 88: 51-55.

Bakus GJ. 2007. Quantitative Analysis of Marine Biological Communities: Field Biology and Environment. WileyInterscience, New Jersey, $435 \mathrm{pp}$. http://dx.doi.org/10.1002/0470099186

Barnard PL, Allan J, Hansen JE, Kaminsky GM, Ruggiero P, Doria A. 2011. The impact of the 2009-10 El Niño Modoki on west coast beaches. Geophys. Res. Lett. 38, L13604. http://dx.doi.org/10.1029/2011GL047707

Blanchette CA, Miner CM, Raimondi PT, Lohse D, Heady KEK, Broitman BR. 2008. Biogeographical patterns of rocky intertidal communities along the Pacific coast of North America. J. Biogeogr. 35: 1593-1607. http://dx.doi.org/10.1111/j.1365-2699.2008.01913.x

Bradley RA, Bradley DW. 1993. Wintering shorebirds increase after kelp (Macrocystis) recovery. Condor 95: 372-376. http://dx.doi.org/10.2307/1369359

Breda VA, Foster MS. 1985. Composition, abundance and phenology of foliose red algae associated with two central California kelp forests. J. Exp. Mar. Biol. Ecol. 94: 115-130. http://dx.doi.org/10.1016/0022-0981(85)90053-X

Broyles B, Felger R, Ezcurra E. 2005. Dry borders: Linking nature reserves across the Sonora-Arizona border. In: Mittermeier RA, Kormos CF, Mittermeier CG, Sandwith T, Besançon C (eds.), Transboundary Conservation: A New Vision for Protected Areas, pp. 128-137.
La rugosidad del sustrato local aparentemente jugó un papel importante en la variación espacial de la diversidad biológica, uno de los criterios biológicos más importantes usados para priorizar sitios de conservación (Roberts et al. 2003). Dado el costo de muestreos y observaciones directas submareales, proponemos que la rugosidad del sustrato puede usarse como un indicador para futuras estimaciones de la diversidad biológica bentónica en estos hábitats. Los bosques de macroalgas se comportaron como ecosistemas complejos con cambios temporales a corto plazo que no fueron consistentes en todos los sitios incluso después de estar expuestos a un evento moderado de El Niño (2009-2010). Tal complejidad requiere de la constante generación de conocimiento de los patrones temporales de los ambientes de bosques algales y sus respuestas esperadas ante perturbaciones. Si queremos predecir cambios en estos hábitats críticos, es necesario implementar actividades de monitoreo para apoyar futuros programas de manejo adaptativo. Los bosques de macroalgas de la costa de Baja California considerados en este estudio son los representantes más al sur de la CSC, donde el intercambio de agua por corrientes los une como una red compartida entre México y los Estados Unidos. No obstante, se requieren estudios adicionales para incluir los cambios locales de la fauna íctica, para estudiar el nivel de conectividad de estos hábitats críticos y para identificar los límites geográficos de la zona de intercambio transfronterizo usando muchas especies de interés. Proponemos que los esfuerzos de conservación regional a largo plazo deberían incorporar este conocimiento ecológico para apoyar las decisiones basadas en la ciencia, la coordinación de políticas binacionales y las prácticas de manejo coherentes incluyendo el diseño de redes de conservación transfronteriza como herramientas de manejo espacial para la protección, conservación y/o restauración del ecosistema de la CSC.

\section{Agradecimientos}

Agradecemos el apoyo brindado por el Consejo Nacional de Ciencia y Tecnología (CONACYT, México) y UCMEXUS mediante una beca doctoral a GTM, así como el apoyo brindado por el Programa Conjunto de Doctorado en Ecología de la Universidad Estatal de San Diego y la Universidad de California en Davis. También agradecemos a Todd Anderson y Rick Grosberg su revisión y comentarios al manuscrito.

Traducido al español por Christine Harris.

Clark RP, Edwards MS, Foster MS. 2004. Effects of shade from multiple kelp canopies on an understorey algal assemblage. Mar. Ecol. Prog. Ser. 267: 107-119. http://dx.doi.org/10.3354/meps267107

Clarke KR, Gorley RN. 2006. PRIMER v6: User Manual/Tutorial. PRIMER-E, Plymouth.

Connell SD. 2003. The monopolization of understorey habitat by subtidal encrusting coralline algae: A test of the combined 
effects of canopy-mediated light and sedimentation. Mar. Biol. 142: 1065-1071.

Dailey MD, Reish DJ, Anderson JW. 1993. Ecology of the Southern California Bight: A Synthesis and Interpretation. University of California Press, Berkeley, 926 pp.

Dayton PK. 1971. Competition, disturbance and community organization: The provision of subsequent utilization of space in a rocky intertidal community. Ecol. Monogr. 41: 351-389. http://dx.doi.org/10.2307/1948498

Dayton PK. 1985. Ecology of kelp communities. Annu. Rev. Ecol. Syst. 16: 215-245. http://dx.doi.org/10.1146/annurev.ecolsys.16.1.215

Dayton PK, Currie V, Gerrodette T, Keller BD, Rosenthal RJ, Tresca DV. 1984. Patch dynamics and stability of some California kelp communities. Ecol. Monogr. 54: 253-289. http://dx.doi.org/10.2307/1942498

Dayton PK, Tegner MJ, Edwards PB, Riser KL. 1998. Sliding baselines, ghosts, and reduced expectations in kelp forest communities. Ecol. Appl. 8: 309-322. http://dx.doi.org/10.1890/10510761(1998)008[0309:SBGARE]2.0.CO;2

Di Lorenzo E. 2003. Seasonal dynamics of the surface circulation in the Southern California Current System. Deep-Sea Res. 50: 2371-2388. http://dx.doi.org/10.1016/S0967-0645(03)00125-5

Duggins DO, Eckman JE, Sewell AT. 1990. Ecology of understory kelp environments. II. Effects of kelps on recruitment of benthic invertebrates. J. Exp. Mar. Biol. Ecol. 143: 27-45. http://dx.doi.org/10.1016/0022-0981(90)90109-P

Durazo R, Ramírez-Manguilar AM, Miranda LE, Soto-Mardones LA. 2010. Climatología de variables hidrográficas. In: GaxiolaCastro G, Durazo R (eds.), Dinámica del Ecosistema Pelágico frente a Baja California 1997-2007. Insituto Nacional de Ecología, Centro de Investigación Científica y Educación Superior de Ensenada, Universidad Autónoma de Baja California, pp. 25-57.

Ebeling AW, Laur DR, Rowley RJ. 1985. Severe storm disturbances and reversal of community structure in a southern California kelp forest. Mar. Biol. 84: 287-294. http://dx.doi.org/10.1007/BF00392498

Edwards MS. 2004. Estimating scale-dependency in disturbance impacts: El Niños and giant kelp forests in the northeast Pacific. Oecologia 138: 436-447. http://dx.doi.org/10.1007/s00442-003-1452-8

Edwards MS, Hernández-Carmona G. 2005. Delayed recovery of giant kelp near its southern range limit in the North Pacific Ocean following El Niño. Mar. Biol. 147: 273-279. http://dx.doi.org/10.1007/s00227-004-1548-7

Edwards MS, Estes JA. 2006. Catastrophe, recovery, and range limitation in NE Pacific kelp forests: A large-scale perspective. Mar. Ecol. Prog. Ser. 320: 79-87. http://dx.doi.org/10.3354/meps320079

Erlandson JM, Torben CR. 2010. Archaeology meets marine Ecology: The antiquity of maritime cultures and human impacts on marine fisheries and ecosystems. Annu. Rev. Mar. Sci. 2: 231-251. http://dx.doi.org/10.1146/annurev.marine.010908.163749

Foster MS, Schiel DR. 1985. The ecology of giant kelp forests in California, USA: A community profile. US Fish and Wildlife Service Biological Rep. I-XV: 1-152.

Foster MS, Vanblaricom GR. 2001. Spatial variation in kelp forest communities along the Big Sur coast of central California, USA. Cryptogamie Algol. 22: 173-186. http://dx.doi.org/10.1016/S0181-1568(01)01054-6
Foster MS, Schiel DR. 2010. Loss of predators and the collapse of southern California kelp forests: Alternatives, explanations and generalizations. J. Exp. Mar. Biol. Ecol. 393: 59-70. http://dx.doi.org/10.1016/j.jembe.2010.07.002

Fowler-Walker MJ, Connell SD. 2007. Habitat heterogeneity as a consequence of substratum-orientation and kelp-canopy: Relating interdependent responses to common patterns. J. Exp. Mar. Biol. Ecol. 343: 127-137. http://dx.doi.org/10.1016/j.jembe.2006.12.004

Fuhlendorf SD, Harrell WC, Engle DM, Hamilton RG, Davis CA. 2006. Should heterogeneity be the basis for conservation? Grassland bird response to fire and grazing. Ecol. Appl. 16: $1706-1716$. http://dx.doi.org/10.1890/10510761(2006)016[1706:SHBTBF]2.0.CO;2

Gaylord B, Rosman JH, Reed DC, Koseff JR, Fram J, MacIntyre S, Arkema K, McDonald C, Brzezinski MA, Largier JL, Monismith SG, Raimondi PT, Mardian B. 2007. Spatial patterns of flow and their modification within and around a giant kelp forest. Limnol. Oceanogr. 52: 1838-1852. http://dx.doi.org/10.4319/1o.2007.52.5.1838

Graham MH. 2004. Effects of local deforestation on the diversity and structure of southern California giant kelp forest food webs. Ecosystems 7: 341-357. http://dx.doi.org/10.1007/s10021-003-0245-6

Graham MH, Edwards MS. 2001. Statistical significance versus factor fit: Estimating the importance of individual factor in ecological analysis of variance. Oikos 93: 505-513. http://dx.doi.org/10.1034/j.1600-0706.2001.930317.x

Graham MH, Vasquez JA, Bushmann AH. 2007. Global ecology of the giant kelp Macrocystis: From ecotypes to ecosystems. Oceanogr. Mar. Biol. 45: 39-88.

Guzmán del Próo SA, Salinas F, Saitzev O, Belmar J, Carrillo J. 2000. Potential dispersion of reproductive products and larval stages of Haliotis spp as a function of the hydrodynamics of Bahía Tortugas, Mexico. J. Shellfish Res. 19: 869-882.

Hammann MG, Rosales-Casián JA. 1990. Taxonomía y estructura de la comunidad de peces del Estero de Punta Banda y Bahía de Todos Santos, Baja California, México. In: de la Rosa-Vélez J, González-Farías F (eds.), Temas de Oceanografía Biológica en México. Universidad Autónoma de Baja California, Ensenada, pp. 153-192.

Hernández-Carmona G, Rodríguez-Montesinos YE, Torres-Villegas JR, Sánchez-Rodríguez I, Vilchis MA. 1989. Evaluation of Macrocystis pyrifera (Phaeophyta, Laminariales) kelp beds in Baja California, Mexico. I. Winter 1985-1986. Cienc. Mar. 15(2): 1-27.

Jones CG, Lawton JH, Shachak M. 1994. Organisms as ecosystem engineers. Oikos 69: 373-386. http://dx.doi.org/10.2307/3545850

Kovalenko KE, Thomaz SM, Warfe DM. 2012. Habitat complexity: Approaches and future directions. Hydrobiologia 685: 1-17. http://dx.doi.org/10.1007/s10750-011-0974-z

Ladah LB, Zertuche-González JA, Hernández-Carmona G. 1999. Giant kelp (Macrocystis pyrifera, Phaeophyceae) recruitment near its southern limit in Baja California after mass disappearance during ENSO 1997-1998. J. Phycol. 35: $1106-1112$. http://dx.doi.org/10.1046/j.1529-8817.1999.3561106.x

Luckhurst BE, Luckhurst K. 1978. Analysis of the influence of substrate variables on coral reef fish communities. Mar. Biol. 49: $317-323$ http://dx.doi.org/10.1007/BF00455026

McClain CR, Barry JP. 2010. Habitat heterogeneity, disturbance, and productivity work in concert to regulate diversity in deep submarine canyons. Ecology 91: 964-976. 
Palleiro-Nayar JS, Aguilar-Montero D, Romero-Martínez JM. 1996. La pesquería del erizo de mar en Baja California, México. Las Pesquerías Relevantes de México. XXX Aniversario del Instituto Nacional de la Pesca, SEMARNAP, pp. 313-335.

Parnell PE, Dayton PK, Lennert-Cody CE, Rasmussen LL, Leichter JJ. 2006. Marine reserve design: Optimal habitats, species affinities, diversity, and ocean microclimate. Ecol. Appl. 16: 945-962.

http://dx.doi.org/10.1890/10510761(2006)016[0945:MRDOSH]2.0.CO;2

Parnell PE, Dayton PK, Fisher RA, Loarie CC, Darrow RD. 2010. Spatial patterns of fishing effort off San Diego: Implications for zonal management and ecosystem function. Ecol. Appl. 20: 2203-2222.

http://dx.doi.org/10.1890/09-1543.1

Pondella D, Gintert BE, Cobb JR, Allen LG. 2005. Biogeography of the nearshore rocky-reef fishes at the southern and Baja California islands. J. Biogeogr. 32: 187-201. http://dx.doi.org/10.1111/j.1365-2699.2004.01180.x

Pondella D, Williams J, Claisse J, Schaffer B, Ritter K, et al. 2011a. A preliminary investigation into the status of nearshore rocky reefs in areas of special biological significance in the Southern California Bight. SCCWRP Technical Report, 38 pp.

Pondella D, Williams J, Claisse J, Schaffer B, Ritter K, et al. 2011 b. Physical and biological characteristics of nearshore rocky reefs in the Southern California Bight SCCWRP Technical Report, $29 \mathrm{pp}$.

Pressey RL, Humphries CJ, Margules CR, Vane-Wright RI, Williams PH. 1993. Beyond opportunism: Key principles for systematic reserve selection. Trends Ecol. Evol. 8: 124-128. http://dx.doi.org/10.1016/0169-5347(93)90023-I

Roberts CM, Andelman S, Branch G, Bustamante RG, Castilla JC, Dugan J, Halpern BS, Lafferty KD, Leslie HM, Lubchenco J, McArdle D, Possingham HP, Ruckelshaus M, Warner RR. 2003. Ecological criteria for evaluating candidate sites for marine reserves. Ecol. Appl. 13: 199-214.

http://dx.doi.org/10.1890/1051-

0761(2003)013[0199:ECFECS]2.0.CO;2

Salgado-Rogel ML, Palleiro-Nayar JS. 2008. Disminución de la abundancia de erizo rojo y propuesta para su manejo en Baja California, México. INAPESCA Cienc. Pesq. 16: 37-45.
Steneck RS, Graham MH, Bourque BJ, Corbett D, Erlandson JM, Estes JA, Tegner MJ. 2002. Kelp forest ecosystems: Biodiversity, stability, resilience and future. Environ. Conserv. 29: 436-459. http://dx.doi.org/10.1017/S0376892902000322

SYSTAT. 2009. SYSTAT for Windows. Version 13. SYSTAT Software Inc., Richmond, California.

Tegner MJ, Dayton PK. 1987. El Niño effects on southern California kelp forest communities. Adv. Ecol. Res. 17: 243-279. http://dx.doi.org/10.1016/S0065-2504(08)60247-0

Tegner MJ, Dayton PK. 2000. Ecosystem effects of fishing in kelp forest communities. ICES J. Mar. Sci. 57: 579-589. http://dx.doi.org/10.1006/jmsc.2000.0715

Tews J, Brose U, Grimm V, Tielbörger K, Wichmann MC, Schwager M, Jeltsch F. 2004. Animal species diversity driven by habitat heterogeneity/diversity: The importance of keystone structures. J. Biogeogr. 31: 79-92. http://dx.doi.org/10.1046/j.0305-0270.2003.00994.x

Toohey BD, Kendrick GA, Harvey ES. 2007. Disturbance and reef topography maintain high local diversity in Ecklonia radiata kelp forests. Oikos 116: 1618-1630. http://dx.doi.org/10.1111/j.0030-1299.2007.15689.x

Ugland KI, Gray JS, Ellingsen KE. 2003. The species accumulation curve and estimation of species richness. J. Anim. Ecol. 72: 888-897. http://dx.doi.org/10.1046/j.1365-2656.2003.00748.x

Watson JR, Hays CG, Raimondi PT, Mitarai S, Dong C, McWilliams JC, Blanchette CA, Caselle JE, Siegel DA. 2011. Currents connecting communities: Nearshore community similarity and ocean circulation. Ecology 92: 1193-1200. http://dx.doi.org/10.1890/10-1436.1

Wilson SK, Graham NAJ, Polunin NVC. 2007. Appraisal of visual assessments of habitat complexity and benthic composition on coral reefs. Mar. Biol. 151: 1069-1076. http://dx.doi.org/10.1007/s00227-006-0538-3

Wolf S, Keitt B, Aguirre-Muñoz A, Tershy B, Palacios E. Croll D. 2006. Transboundary seabird conservation in an important North American marine ecoregion. Environ. Conserv. 33: 294-305. http://dx.doi.org/10.1017/S0376892906003353

Received October 2012, Received in revised form March 2013, accepted April 2013. 